\title{
Mercury exposure in a low-income community in South Africa
}

\author{
M A Oosthuizen, J John, V Somerset
}

Objectives. To establish whether a specific community in a gold mining area, with potentially associated small-scale gold mining activities, was exposed to mercury.

Methods. The community was situated in Mpumalanga, where some potential sources of mercury emissions may have an impact. Adults $\geq 18$ years were considered eligible. Biological monitoring, supported by questionnaires, was applied. Thirty respondents completed the questionnaire which covered demographics, energy use, food and water consumption, neurological symptoms, and confounders such as alcohol consumption and brain injuries. Mercury levels were determined in 28 urine and 20 blood samples of these respondents.

Results. Three (15\%) of the blood samples exceeded the guideline $(<10 \mu \mathrm{g} / \mathrm{l})$ for individuals who are not occupationally exposed, while $14(50 \%)$ of the urine samples exceeded the guideline for mercury in urine $(<5.0$

Coal combustion and gold mining are sources of mercury pollution. ${ }^{1,2}$ Estimates suggest that South Africa is second only to China in terms of mercury emissions to the environment. ${ }^{1}$ However, refined estimates indicate that lower levels emanate from coal combustion in power plants. ${ }^{3}$ More than $90 \%$ of electricity generated in South Africa is from coal-fired power plants that are considered to be the biggest source of mercury in the country as they consume $112 \mathrm{Mt}$ of coal annually, and release $9.8 \mathrm{t}$ of mercury. Comparing the per capita emissions of mercury from coal-fired power plants in South Africa to those in Canada, China, Europe, Mexico, Poland, Russia and the USA, South Africa is ranked second. ${ }^{3}$

South Africa is also a major producer of gold but production has declined from between 600 and $700 \mathrm{t}$ in 1985 to between 300 and $400 \mathrm{t}$ in 2004. ${ }^{4}$ Since 2007, China has surpassed South Africa as the world's largest gold producer. ${ }^{5}$ It is estimated that gold production from large and small-scale mining in Africa accounts for about $45 \%$ of total mercury emissions on the continent. $^{3}$

Other sources of mercury exposure include releases from dental fillings containing mercury, consumption of contaminated fish and breakage of mercury-containing devices such as thermometers and fluorescent lights. ${ }^{6}$

Natural Resources and the Environment Business Unit, CSIR, Pretoria M A Oosthuizen, MMedSc

J John, MSc

Natural Resources and the Environment Business Unit, CSIR, Stellenbosch V Somerset, $\mathrm{PhD}$

Corresponding author: M Oosthuizen (roosthui@csir.co.za) $\mu \mathrm{g} / \mathrm{g}$ creatinine) for those not exposed occupationally. The cause of these elevated levels is unknown, as only $20 \%$ of respondents indicated that they used coal as an energy carrier. Furthermore, nobody from the community was reportedly formally employed in a goldmine. Nineteen (63\%) respondents consumed locally caught fish, while 20 (67\%) drank water from a river.

Conclusions. Some individuals in this study may be occupationally exposed to mercury through small-scale gold mining activities. As primary health facilities will be the first point of entry for individuals experiencing symptoms of mercury poisoning, South African primary health care workers need to take cognisance of mercury exposure as a possible cause of neurological symptoms in patients.

S Afr Med J 2010; 100: 366-371.
Mercury is toxic even at low concentrations, ${ }^{7}$ particularly the organic form of mercury called methylmercury, which accumulates in the food chain. Methylation of inorganic mercury in the environment into organic mercury occurs in the presence of sulphate-reducing bacteria under anaerobic conditions, e.g. in underwater sediments.

The extent of mercury exposure in communities in South Africa is largely unknown. Dalvie and Ehrlich ${ }^{8}$ studied the effect of mercury inhalation in a community in Cape Town. Mercury concentrations in urine samples from residents in the vicinity of waste sites and fossil fuel-burning operations were compared with those from a control area. Although the median concentrations of mercury in the urine found in both groups were below the World Health Organization (WHO) guideline value of $5 \mu \mathrm{g} / \mathrm{g}$ creatinine, a statistically significant difference $(p<0.05)$ was noted between the two groups, the exposed group having higher concentrations than the control group (median $1.1 \mathrm{v} .0 .25 \mu \mathrm{g} / \mathrm{g}$ creatinine; 90th percentile $6.7 \mathrm{v} .2 .4 \mu \mathrm{g} / \mathrm{g}$ creatinine).

A study in Peru, focusing on smelters and those living in the vicinity ( $N=33$ ), found high levels (mean $728 \mu \mathrm{g} / \mathrm{l}$ ) of mercury in the urine of those directly involved in smelting $(N=6)$, compared with controls $(4 \mu \mathrm{g} / \mathrm{l}) .^{9}$ In Tanzania, urinary mercury concentrations found in $36 \%$ of individuals $(N=45)$ involved in amalgamation were between 50 and $100 \mu \mathrm{g} / \mathrm{g}$ creatinine, with 4 samples $>100 \mu \mathrm{g} / \mathrm{g}$ creatinine. The mean mercury level in control urine samples was $5 \mathrm{ug} / \mathrm{g}$ creatinine. ${ }^{10}$ In a small-scale gold mining community in the Philippines, 39 adults and 14 of their children under the age of 12 years were studied; 19 men were directly exposed to mercury, while the remaining adults were indirectly exposed. The highest mean blood mercury levels ( $15 \mathrm{ng} / \mathrm{g}$ creatinine) were found in the directly exposed adults, compared with the indirectly exposed adults $(9 \mathrm{ng} / \mathrm{g}$ creatinine) and children $\left(7 \mathrm{ng} / \mathrm{g}\right.$ creatinine) ${ }^{11}$ 
We report on a pilot study conducted in Mpumalanga province. The availability of data on mercury levels in the local water and fish contributed to the selection of this community. Our purpose was to establish whether a specific community in a gold mining area, with potentially associated small-scale gold mining activities, was exposed to mercury. We concluded that individuals in this community may be exposed to mercury levels similar to those occurring in an occupational environment, and these results could therefore be used to improve management of human health and environmental risks from mercury exposure.

\section{Materials and methods}

\section{Study area and population}

The study area was selected close (within a $5 \mathrm{~km}$ radius) to formal gold mining activities in Mpumalanga province, where 8 of the country's 10 coal-fired power plants operate. The study population was from a community close to a river, from which they obtained water and fish for daily consumption. The predominant languages spoken by respondents were Swazi (77\%), Tsonga (13\%) and Zulu (10\%); $63 \%$ of the people had lived in this area for more than 10 years. The community lived in unplanned and informal dwellings, situated far apart and in dense vegetation, making it impossible to determine the extent of the population and the number of households in the area.

\section{Study design}

A cross-sectional study was planned but, owing to the distribution of dwellings, it was not possible to locate individual households for random selection. We therefore decided to inform residents about a planned visit during which individuals possibly exposed to mercury could be identified. Community members were requested to gather at a specific time and place. This exercise was repeated 3 times, and the 30 individuals who participated voluntarily therefore formed the sample size. As sampling was not random, but relied on individuals who arrived for sampling, this is a form of participation bias that limits the type of inferences possible. If individuals with elevated levels of mercury were found, it may be inferred that such levels exist within this community. However, quantifying the extent (prevalence) of such elevated levels within this community based on the proportion found in the study group would not be possible.

\section{Data collection}

The study was approved by the Ethics Committee of the University of Pretoria (certificate number 108/2007). Data collection consisted of biological monitoring and interviews with consenting community members $\geq 18$ years old.

One trained field worker conducted the interviews by means of a structured questionnaire based on published questionnaires used in studies on mercury exposure, ${ }^{12}$ after written informed consent from the respondents. It comprised 6 sections (variables indicated in Table I): demographics, living conditions, exposure parameters, lifestyle, health outcomes and possible confounders of mercury exposure (such as brain injuries and alcohol consumption) that may cause symptoms resembling those of mercury poisoning.
A registered nursing sister collected 'spot' blood samples (in ethylene diamine tetra-acetic acid (EDTA) vacuumed tubes) and urine samples (in sterile polypropylene bottles) from respondents. A total of 20 blood samples and 28 urine samples were collected; 18 respondents gave blood and urine samples, 2 gave only a blood sample and 10 only a urine sample.

Ampath, a South African National Accreditation System (SANAS) accredited pathology laboratory, performed total mercury (HgT) analysis using atomic absorption spectroscopy (AAS), coupled with a hydride generation system. Urinary mercury concentrations were adjusted for urinary creatinine concentrations to compensate for hydration state.

Community residents consumed water and fish from a nearby river. A monitoring study at the same river, conducted by the CSIR within 6 months of this study, detected mercury levels in fish and water that were below the guideline values for consumption. ${ }^{13,14}$

\section{Data management}

Completed questionnaires were coded and entered into EpiData using the double-data entry method. Categorical data were summarised by means of frequencies and percentages. Data were analysed using Stata Release version 10.0. Data were tested for association with risk or environmental factors using Pearson's chi-square test or, when applicable, Fisher's exact test. The crude (unadjusted) odds ratios (ORs) along with their 95\% confidence intervals (CIs) were also determined.

\section{Results and discussion}

\section{Study population profile}

Questionnaire responses provide the descriptive statistics for demographics and exposure profiles (Table Ia). A contract worker on a farm and a tuck shop owner indicated that they were employed at the time. Seventy-four per cent of all respondents, irrespective of the source of their drinking water, indicated that they consumed between 1 and 21 of water per day. Regarding whether a respondent had ever had contact with mercury (as a miner or otherwise), only 3 had previous training in mining activities, and 1 individual had possible exposure for up to 20 years. None used coal for space heating; 3 of the 14 respondents with elevated mercury levels in their urine used coal for cooking.

Table Ib provides descriptive statistics for lifestyle, health status and possible confounders, using questionnaire responses. Concerning possible brain injury as a confounding factor, 3 of the 6 individuals who indicated that they were ever unconscious for $>1$ hour after an accident, had elevated mercury levels.

\section{Blood and urine analysis}

Mercury levels in the 20 blood samples ranged from $<0.5$ to $24.0 \mu \mathrm{g} / \mathrm{l}$ (median $2.35 \mu \mathrm{g} / \mathrm{l}$ ). The normal level for those who are not occupationally exposed is $<10 \mu \mathrm{g} / 1$ (Table II). In a study in the USA, the geometric mean of total blood mercury in individuals $\geq 1$ year was $<1 \mathrm{ug} / 1 .{ }^{17}$

Fig. 1 depicts the results of the urine mercury analysis: 28 urine samples were collected, and mercury levels ranged from 


\section{Original Articles}

Table Ia. Descriptive statistics for demographics and exposure profiles using questionnaire responses from the study sample

\begin{tabular}{|c|c|c|c|c|}
\hline & Variable & Category & $\begin{array}{l}\text { Number in } \\
\text { sample }(N=30)\end{array}$ & $\begin{array}{c}\text { Percentage of } \\
\text { sample (\%) }\end{array}$ \\
\hline \multirow[t]{11}{*}{ Demographics } & \multirow[t]{2}{*}{ Gender } & Male & 12 & 40 \\
\hline & & Female & 18 & 60 \\
\hline & \multirow[t]{3}{*}{ Education } & No formal education & $15(N=29)$ & 52 \\
\hline & & Education up to Grade $9^{*}$ & $6(N=29)$ & 21 \\
\hline & & Education higher than Grade 9 & $8(N=29)$ & 27 \\
\hline & \multirow[t]{3}{*}{ Home language } & Swazi & 23 & 77 \\
\hline & & Zulu & 3 & 10 \\
\hline & & Other (specified as Tsonga) & 4 & 13 \\
\hline & \multirow[t]{3}{*}{ Current employment } & Full time & 1 & 3 \\
\hline & & Self-employed & 1 & 3 \\
\hline & & Unemployed & 28 & 97 \\
\hline \multirow[t]{4}{*}{ Living conditions } & \multirow{4}{*}{$\begin{array}{l}\text { Home constructed } \\
\text { mainly of: }\end{array}$} & Brick/block & 3 & 10 \\
\hline & & Mud (wattle and dab) & 14 & 47 \\
\hline & & Corrugated iron (zinc) & 11 & 36 \\
\hline & & Wood & 2 & 7 \\
\hline \multirow[t]{16}{*}{ Exposure } & \multirow{2}{*}{$\begin{array}{l}\text { Time of residence } \\
\text { in community }\end{array}$} & In area for $>10$ years & 19 & 63 \\
\hline & & In area for $>5<10$ years & 6 & 20 \\
\hline & $\begin{array}{l}\text { Distance resident } \\
\text { from gold mine }\end{array}$ & $<5 \mathrm{~km}$ away & 27 & 90 \\
\hline & \multicolumn{4}{|l|}{ Ever had contact with: } \\
\hline & - mercury or worked as a miner & Yes & 7 & 23 \\
\hline & - training in mining activities & & 3 & 10 \\
\hline & \multicolumn{2}{|l|}{ melted gold in open pans } & 3 & 10 \\
\hline & \multicolumn{2}{|l|}{ - burnt amalgam at home } & 1 & 3 \\
\hline & \multicolumn{2}{|l|}{$\begin{array}{l}\text { - stored mercury in } \\
\text { containers or flasks }\end{array}$} & 2 & 7 \\
\hline & \multirow{4}{*}{$\begin{array}{l}\text { - had a mercury spill } \\
\text { Source of drinking water }\end{array}$} & & 1 & 3 \\
\hline & & Municipal water (treated) & 3 & 10 \\
\hline & & Local river $^{\dagger}$ & 20 & 67 \\
\hline & & Community borehole & 7 & 23 \\
\hline & Fish consumption & Locally caught once or more a week & $\kappa^{\ddagger} 19$ & 63 \\
\hline & \multirow{2}{*}{ Energy use } & Coal for cooking & 6 & 20 \\
\hline & & Coal for space heating & 0 & 0 \\
\hline \multicolumn{5}{|c|}{${ }^{*}$ Grade 9 is the minimum compulsory education in South Africa. } \\
\hline \multicolumn{5}{|c|}{${ }^{\dagger}$ Concentrations of HgT ranged from 3.16 to $3.81 \mathrm{ng} / \mathrm{l}^{13}$ which is below the South African target water quality guideline of $1000 \mathrm{ng} / 1(1 \mathrm{\mu g} / \mathrm{l})$ for domestic use. ${ }^{15}$} \\
\hline \multicolumn{5}{|c|}{ 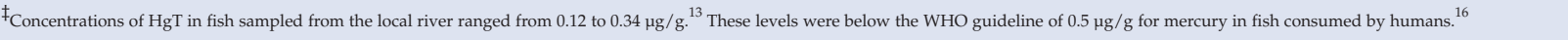 } \\
\hline
\end{tabular}

0.5 to $63.5 \mu \mathrm{g} / \mathrm{g}$ creatinine (median $6.2 \mu \mathrm{g} / \mathrm{g}$ creatinine). The urine mercury levels expressed as $\mu \mathrm{g} / 1$ urine ranged from $<0.5$ $\mu \mathrm{g} / 1$ to $181.1 \mu \mathrm{g} / \mathrm{l}$. Some results exceeded even occupational limit values of the South African occupational and nonoccupational exposure guideline values for mercury in urine (Table II).

When mercury levels in urine are $>40 \mu \mathrm{g} / 1$, symptoms such as fever, tremors, mood swings, insomnia and acrodynia (pink disease in children) may develop; at levels $>60 \mu \mathrm{g} / \mathrm{l}$, additional respiratory symptoms may develop. Below $40 \mu \mathrm{g} / \mathrm{l}$, symptoms are thought to be unlikely. ${ }^{6}$ However, a study in Sweden ${ }^{18}$ reported central nervous system symptoms involving 96 occupationally exposed individuals with a median mercury level in urine of $25 \mu \mathrm{g} / \mathrm{g}$ creatinine. Another study found renal effects in workers with levels $>20 \mu \mathrm{g} / \mathrm{g}$ creatinine. ${ }^{19}$

Five of the 7 individuals in our study who confirmed that they had previously worked as miners or had contact with mercury, had elevated mercury levels in their urine, ranging from $9 \mu \mathrm{g} / \mathrm{g}$ creatinine (or $19.8 \mu \mathrm{g} / 1$ urine) to $63.5 \mu \mathrm{g} / \mathrm{g}$ creatinine (or $76.2 \mu \mathrm{g} / 1$ urine). The latter result was from an individual who also had an elevated blood mercury level of
$24 \mu \mathrm{g} / \mathrm{l}$ and who indicated that he had been occupationally exposed for up to 20 years.

Despite few respondents indicating that they had had contact with mercury at some stage in their lifetime, 14 had elevated mercury levels in either their urine, blood or both. They were referred to the occupational outpatient clinic at a nearby hospital.

Because random sampling was not possible, this study could not determine the prevalence of mercury exposure in the community. However, some community members are being exposed to mercury, possibly attributable to mercury used in the mercury-gold amalgamation process used in small-scale gold mining activities.

\section{Variables that showed elevated crude odds ratios}

The results of the urine samples were divided according to the South African guidelines for mercury in urine for different exposure groups (Table II). Blood samples that exceeded the guideline for individuals not occupationally exposed were defined as 'elevated' (Table III). 


\section{Original Articles}

Table Ib. Descriptive statistics for lifestyle, health and possible confounders using questionnaire responses from the study sample

\begin{tabular}{|c|c|c|c|c|}
\hline & Variable & Category & $\begin{array}{l}\text { Number in } \\
\text { sample }(N=30)\end{array}$ & $\begin{array}{c}\text { Percentage of } \\
\text { sample (\%) }\end{array}$ \\
\hline Lifestyle & Currently smoke & Yes & 12 & 40 \\
\hline Health & $\begin{array}{l}\text { Metallic taste in mouth } \\
\text { Bad appetite } \\
\text { Weight loss }>10 \mathrm{~kg} \text { in past year } \\
\text { Marked hair loss in past year } \\
\text { Coughed more than } 3 \text { months } \\
\text { in past year } \\
\text { Pneumonia in past year } \\
\text { Asthma in past } 6 \text { months } \\
\text { Tire easily } \\
\text { Tremors } \\
\text { Palpitations } \\
\text { Headaches } \\
\text { Numbness, prickling, } \\
\text { aching in body } \\
\text { Feel nervous often } \\
\text { Feel sad often } \\
\text { Problem concentrating }\end{array}$ & Yes & $\begin{array}{l}4 \\
9 \\
5 \\
2 \\
3 \\
2 \\
1 \\
5 \\
1 \\
8 \\
15 \\
5 \\
4 \\
8 \\
5\end{array}$ & $\begin{array}{l}13 \\
30 \\
17 \\
7 \\
10 \\
7 \\
7 \\
3 \\
17 \\
3 \\
27 \\
50 \\
17 \\
\\
13 \\
27 \\
17\end{array}$ \\
\hline $\begin{array}{l}\text { Possible } \\
\text { confounders }\end{array}$ & $\begin{array}{l}\text { Frequency of alcohol consumption } \\
\text { Diseases ever had: } \\
\text { Epilepsy } \\
\text { Stroke } \\
\text { Parkinson } \\
\text { Depression } \\
\text { Malaria } \\
\text { Liver disease } \\
\text { Tuberculosis } \\
\text { Brain injuries } \\
\text { Use handle/work with: } \\
\text { Petrol/paraffin } \\
\text { Pesticides }\end{array}$ & $\begin{array}{l}\text { None } \\
\text { Monthly } \\
\text { Weekly } \\
\text { Yes } \\
\\
\text { Ever unconscious for } \\
>1 \text { hour after accident } \\
\text { Yes }\end{array}$ & $\begin{array}{l}19 \\
7 \\
4 \\
1 \\
1 \\
0 \\
0 \\
5 \\
2 \\
1 \\
6\end{array}$ & $\begin{array}{l}63 \\
23 \\
13 \\
\\
3 \\
3 \\
0 \\
0 \\
17 \\
7 \\
3 \\
20\end{array}$ \\
\hline
\end{tabular}

Table II. South African guidelines for mercury in blood and urine

\begin{tabular}{|c|c|c|}
\hline & $\begin{array}{c}\text { Not occupationally } \\
\text { exposed }\end{array}$ & $\begin{array}{c}\text { Occupationally exposed: } \\
\text { prior to shift } \text { BEI* }^{*}\end{array}$ \\
\hline Urine & $\begin{array}{l}<5.0 \mu \mathrm{g} / \mathrm{g} \\
\text { creatinine }\end{array}$ & $\begin{array}{l}<35 \mu \mathrm{g} / \mathrm{g} \\
\text { creatinine }\end{array}$ \\
\hline Blood & $<10 \mu \mathrm{g} / 1$ & $15 \mu \mathrm{g} / 1$ \\
\hline \multicolumn{3}{|c|}{$\begin{array}{l}\text { *Based on South African Biological Exposure Index (BEI) Occupational Safety and Health Act (Act } 85 \\
\text { of 1993). }\end{array}$} \\
\hline
\end{tabular}

Logistic regression analyses were performed, and crude ORs $>1.5$ for risk factors associated with the groups representing elevated blood and urine levels are shown in Table III. None was statistically significant, possibly owing to the small study population, which was also the reason for the wide CIs. However, the biological monitoring indicated that both exposed and non-exposed individuals were included, which suggests sufficient variability. Therefore, factors that showed elevated crude ORs may be regarded as indicative of potential risks warranting further investigation.

Previous contact with mercury (e.g. having burnt amalgam at some stage and being a smoker) nearly doubled an individual's risk of having urine mercury levels ranging between 5.1 and 35

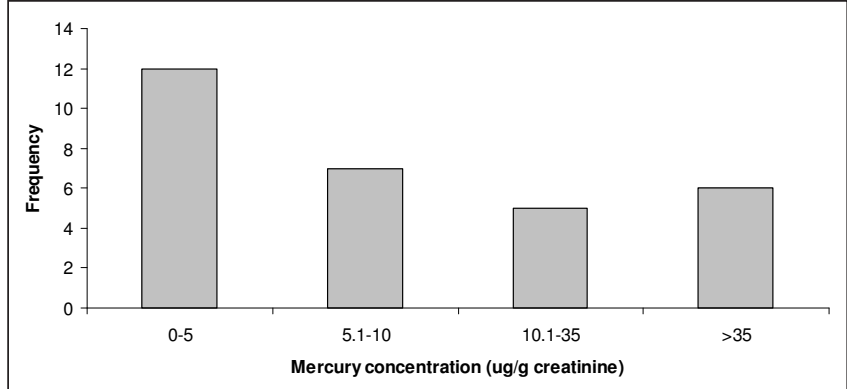

Fig. 1. Frequency of cases at different levels of mercury in urine.

$\mu \mathrm{g} / \mathrm{g}$ creatinine (Group 1), while consuming alcohol monthly and having ever had an accident where the individual was unconscious for $>1$ hour, constituted a nearly four times higher risk. Having a metallic taste in the mouth and often feeling sad were associated with about a 3 times higher risk of having mercury levels in urine between 5.1 and $35 \mu \mathrm{g} / \mathrm{g}$ creatinine. Previous contact with mercury was associated with a 4 times higher risk of having mercury in urine $>35 \mu \mathrm{g} / \mathrm{g}$ creatinine (Group 2). Being a smoker and having ever had an accident where the individual was unconscious for $>1$ hour was associated with a 7 times higher risk, while feeling sad was associated with a 3 times higher risk. 


\begin{tabular}{|c|c|c|c|}
\hline Risk factor & Crude OR & $95 \%$ CI & $p$-value \\
\hline \multicolumn{4}{|c|}{ Elevated urine level (Group 1: >5.1 <35 $\mu \mathrm{g} / \mathrm{g}$ creatinine) } \\
\hline Previous contact with mercury & 2.27 & $0.34 ; 15.36$ & 0.39 \\
\hline Ever burnt amalgam & 1.57 & $0.12 ; 20.72$ & 0.73 \\
\hline Smoker & 2.33 & $0.43 ; 12.78$ & 0.31 \\
\hline Consume alcohol monthly & 3.64 & $0.32 ; 41.88$ & 0.27 \\
\hline Had an accident & 3.67 & $0.32 ; 42.03$ & 0.26 \\
\hline Metallic taste in mouth & 2.54 & $0.21 ; 30.08$ & 0.44 \\
\hline Feeling sad & 3.00 & $0.44 ; 20.22$ & 0.24 \\
\hline \multicolumn{4}{|c|}{ Elevated urine level (Group 2: >35 $\mu \mathrm{g} / \mathrm{g}$ creatinine) } \\
\hline Previous contact with mercury & 3.80 & $0.38 ; 37.85$ & 0.22 \\
\hline Smoker & 7.29 & $0.53 ; 100.50$ & 0.08 \\
\hline Had an accident & 7.00 & $0.58 ; 84.99$ & 0.08 \\
\hline Feeling sad & 3.00 & $0.32 ; 28.44$ & 0.31 \\
\hline \multicolumn{4}{|l|}{ Elevated blood level (>10 ug/l) } \\
\hline Previous contact with mercury & 3.75 & $0.19 ; 72.40$ & 0.35 \\
\hline Smoker & 4.80 & $0.29 ; 78.64$ & 0.22 \\
\hline Had an accident & 2.33 & $0.14 ; 38.48$ & 0.54 \\
\hline Metal taste in mouth & 3.75 & $0.19 ; 72.40$ & 0.34 \\
\hline Difficulty in concentrating & 2.33 & $0.14 ; 38.48$ & 0.54 \\
\hline
\end{tabular}

There was a 4 times higher risk of having elevated blood mercury levels if there had been previous contact with mercury and a metallic taste in the mouth. Difficulty to concentrate was associated with twice the risk of elevated blood mercury levels. Being a smoker and having had an accident and being unconscious for $>1$ hour increased the risk 5 and 2 times, respectively.

Being a smoker alone does not cause direct exposure to high levels of mercury. However, a smoker who handles mercury may be exposed via hand-to-mouth contact. Alcohol consumption and brain injuries are regarded as confounders rather than risk factors for elevated mercury levels in blood and urine.

\section{Implications of elevated mercury levels found in biological samples}

Fifteen per cent of the blood samples and $50 \%$ of the urine samples exceeded the guidelines for individuals not occupationally exposed (Table II).

The cause for the elevated mercury levels cannot be explained by the following known exposure factors for mercury: coal is not the preferred domestic energy carrier used by the community; mercury concentrations detected in the river water and fish samples were below guideline values for human consumption; and none of the respondents was formally employed, indicating that they were not occupationally exposed at the time of the study.

Since most respondents had no schooling or other formal education, and only 2 were employed, the use of mercury in small-scale gold mining activities could be responsible for the elevated mercury levels in their blood and urine. However, small-scale gold mining is illegal in South Africa, which could have caused reluctance to admit involvement.

Approximately 20000 miners participate in artisanal smallscale gold mining (ASM) activities in South Africa. ${ }^{20}$ The use of mercury increases with ASM activities because it is used to make an amalgam with gold during ore processing. Gold amalgamation is popular among small-scale miners because it efficiently extracts fine gold particles from the mining concentrates, and the equipment is inexpensive. The amalgam is then heated in an open container or a closed retort. Elemental mercury $\left(\mathrm{Hg}^{0}\right)$, the main form of mercury released to the air by ASM, is very volatile and contributes to the anthropogenic pool of mercury. ${ }^{12}$ For every gram of gold produced through small-scale gold mining, $1.2-1.5 \mathrm{~g}$ of mercury is emitted to the environment, of which $70-80 \%$ is to the atmosphere. ${ }^{21}$

Small-scale gold miners are probably unaware of the dangers of using mercury in the amalgamation process but, lacking capital, they may have no alternative. This may lead to participants in small-scale mining operations ignoring issues related to health, safety and environmental management.

The lack of reliable data on small-scale mining sites, their production figures, total number of workers, age, gender, and cultural perceptions, limits the development of effective assistance programmes and the improvement of their safety and health performance. Contributing to this problem is that these operations are often illegal in South Africa; such miners invariably do not have a mining permit or other form of authorisation from the Department of Minerals and Energy (DME), or permission from the owners of the ground on which they operate. The extent of the problem is therefore unknown and very difficult to address, especially from a human health perspective.

Illegal mining poses several problems; for example, if an illegal miner dies on mine property, the matter may become the responsibility of the mine owner. Illegal miners also encourage illegal dealing in mercury supply and cross-border sale of gold. Revenues generated from illegal mining will not be subject to South African taxation, which could be a further incentive to continue mining illegally. 


\section{OriginAl ARTICLES}

\section{Conclusion and recommendation}

Despite not being able to determine the prevalence of mercury exposure in the specific community because random sampling was not possible, this study concurs with findings of elevated mercury levels in individuals occupationally exposed to mercury. Therefore, we can conclude that the individuals in this study may be similarly exposed to mercury possibly from small-scale gold mining activities. This practice will probably continue while poverty drives the miners to continue such operations. As primary health facilities will be the first point of entry for individuals experiencing symptoms of mercury poisoning, workers at these facilities should be equipped to correctly diagnose and refer such individuals.

The authors express their gratitude to the community involved in this study and to the rest of the team members involved. This research was further supported by funding by the CSIR's parliamentary grant.

\section{References}

1. Pacyna EG, Pacyna JM, Steenhuisen F, Wilson S. Global anthropogenic mercury emission inventory for 2000. Atmos Environ 2006; 40: 4048-4063.

2. Wilson SJ, Steenhuisen F, Pacyna JM, Pacyna EG. Mapping the spatial distribution of global anthropogenic mercury atmospheric emission inventories. Atmos Environ 2006; 40: 621-4632. 3. Dabrowski JM, Ashton PJ, Murray K, Leaner JJ, Mason RP. Anthropogenic mercury emissions in South Africa: Coal combustion in power plants. Atmos Environ 2008; 42: 6620-6626.

4. DME (Department of Minerals and Energy). South Africa's Mineral Production and Sales 1985 2004. DME Report number R50/2005. http://www.dme.gov.za/pdfs/minerals/R50\%20-\%20 update\%202007.pdf (accessed 8 February 2010).
5. Washington Post. China overtook SA to become world' top gold producer in 2007. Washington Post Saturday 19 December 2009. http:/ /www.washingtonpost.com/wp-dyn/ content/article/2009/12/18/AR2009121804175.html (accessed 8 February 2010).

6. ATSDR (Agency for Toxic Substances and Disease Registry). ToxFAQs: CABS Chemical Agent Briefing Sheet 2006. http:/ / www.atsdr.cdc.gov/cabs/mercury/mercury_cabs.pdf (accessed 5 February 2010

7. Zahir F, Rizwi SJ, Haq SK, Khan RH. Low dose mercury toxicity human health. Environ Toxicol Phar 2005; 30: 351-360.

8. Dalvie MA, Ehrlich R. Community mercury levels in the vicinity of peri-urban waste disposal sites and fossil fuel burning operations. Environ Int 2006; 32: 493-499.

9. Hurtado J, Conzales GF, Steenland K. Mercury exposures in informal gold miners and relatives in Southern Peru. Int J Occup Environ Health 2006; 12: 340-345.

10. Van Straaten P. Human exposure to mercury due to small-scale gold mining in northern Tanzania. Sci Total Environ 2000; 259: 45-53.

11. Cortes-Maramba N, Reyes JP, Francisco-Rivera AT, Akagi H, Sunio R, Panganiban LC. Health and environmental assessment of mercury exposure in a gold mining community in Western Mindanao, Philippines. J Environ Manage 2006; 81: 126-134.

12. Veiga M, Baker R. Protocols for environmental and health assessment of mercury released by artisanal and small-scale gold miners. Removal of barriers to introduction of cleaner artisanal gold mining and extraction technologies. Vienna: Project EG/GLO/01/G34. ISBN 92-1-106429-5, 2004: 289.

13. Oosthuizen MA, John J, Somerset V. CSIR Report number CSIR/NRE/WR/IR/2009/0013/A. Pretoria: CSIR, 2009.

14. Williams C, Somerset V. Trace Metal Laboratory Quality Assurance Qa)/Quality Control (Qc). CSIR Report number CSIR/NRE/WR/IR/2010/0016/B. Pretoria: CSIR, 2010.

15. Department of Water Affairs and Forestry (DWAF). South African Water Quality Guidelines: Volume 1: Domestic Use. Report No. P09000/00/0101. Pretoria: Department of Water Affairs an Forestry, 1996. http:/ / www.dwaf.gov.za/Dir_WQM/docsFrame.htm (accessed 23 October 2009).

16. World Health Organization (WHO). Environmental health criteria for mercury. In: Environmental Health Criteria 1. Mercury. Geneva: World Health Organization, 1976.

17. Caldwell KL, Mortensen ME, Jones RL, Caudill SP, Osterloh JD. Total blood mercury concentrations in the U.S. population: 1999-2006. Int J Hyg Environ Health 2009; doi:10.1016/j. ijheh.2009.04.004

18. Langworth S, Almkvist, Söderman E, Wikström B-O. Effects of occupational exposure to mercury vapour on the central nervous system. Brit J Ind Med 1992; 48: 545-555.

19. World Health Organization. Elemental Mercury and Inorganic Mercury Compounds: Human Health Aspects. ISBN 924153050 2. Geneva: World Health Organization, 2003.

20. Hilson GM. The future of small-scale mining: environmental and socioeconomic perspectives Futures 2002; 34: 864-872.

21. Van Straaten P. Mercury contamination associated with small-scale gold mining in Tanzania and Zimbabwe. Sci Total Environ 2000a; 259: 105-113.

Accepted 15 February 2010. 